\title{
ROLE OF PURWOKERTO FINANCIAL SERVICES AUTHORITY IN IMPROVING SHARIA BANKING MARKET SHARE
}

\author{
Aditya Putri Lidyaningtyas ${ }^{1 *}$, Makhrus $^{2}$ \\ 1,2Universitas Muhammadiyah Purwokerto \\ *Corresponding Author Email: its.adityaputri@gmail.com
}

This is an open access article distributed under the Creative Commons Attribution License, which permits unrestricted use, distribution, and reproduction in any medium, provided the original work is properly cited.

\section{ARTICLE DETAILS}

\section{Article History:}

Received 10 July 2019

Accepted 12 August 2019

Available online 23 August 2019

\section{ABSTRACT}

This study aims to determine the role and strategy of the Purwokerto Regional Office of the Financial Services Authority in increasing the market share of sharia banking. This type of research is qualitative descriptive and data collection is done by interview, adequacy of references, and documents. The results of this study indicate that in increasing market share of sharia banking, the Financial Services Authority of the Purwokerto Regional Office conducts activities including the dissemination of sharia banking, seminars, financial literacy and inclusion in collaboration with islamic banks, educational institutions, and community organizations. In the activities that have been carried out it is able to give a positive impact on the knowledge and understanding of the community to get to know the products and transact in sharia banking. In addition, the positive impact has also increased the public's interest to know and transact in other islamic financial institutions. Institutionally, the development of sharia banking in the Financial Services Authority of the Purwokerto Regional Office has increased significantly each year. Even though, these developments are not evenly distributed as happened in Banjarnegara Regency, so that a special strategy is needed, for example to pay more attention to the condition of the community, geographical, sociological, etc. so that the growth of sharia banking in the Banyumas residency area is more evenly distribute.

\section{KEYWORDS}

Financial Services Authority, Market Share, Sharia banking.

\section{INTRODUCTION}

The establishment of Sharia banking in Indonesia is influenced by the awareness of Muslim communities who want to carry out all financial activities based on the Qur'an and Sunnah. This means that guarantees regarding the fulfillment of sharia in all customer fund management activities are fundamental, because Sharia banking is bound by ethical values, responsibility and philanthropy [1].

The banking industry in Indonesia is divided into banks that operate based on interest (conventional banks) and banks that operate based on profit sharing principles (Islamic or sharia banks). The Sharia banking system is different from conventional banking systems, because the financial system in Sharia banking is a subsystem of an Islamic economic system with a broader scope. Sharia banking is not only required to generate profits commercially, but also demanded to be serious in displaying the realization of sharia values. Even though, both systems rely on the trust of their customers, because trust has a significant relationship with a customer's commitment [2].

Regulatively, the existence of Sharia banking in Indonesia has only been enacted in 2008, even though the practice has been going on since 1991. In order to support the effectiveness of supervision of Islamic financial institutions (including Islamic financial institutions) the government issued Law No. 21 of 2011 concerning the Financial Services Authority. The law states that the Financial Services Authority (OJK) has the function of organizing an integrated regulation and supervision system for all activities in the financial services sector. The effectiveness of OJK's supervision of Sharia banking relies heavily on coordination between 0JK and Sharia banking [3]. This is because there are fundamental differences between Islamic banks and conventional banks, namely Islamic banks in operating their business activities based on sharia principles, while conventional banks are based on the principle of interest. This difference results in fundamental differences in the corporate governance structure and the Sharia banking supervision system. While the supervision of
Sharia banking basically has two systems, namely: first, supervision of the financial aspects, compliance with banks in general and the principle of bank prudence. Second, supervision of sharia principles in bank operations.

While relating to the potential of Sharia banking in Indonesia is very potential. Based on the 0JK report in 2017 the national market share of Sharia banking has only reached $5.78 \%$ of all national banks. This means that the prospect of Sharia banking is very potential, this is because Indonesia is the country with the most Islamic population and a shariabased industry that is growing rapidly [4]. The relationship between the two, on the other hand, illustrates that the existence of Sharia banking and other financial industries, in fact, has a positive impact on the implementation of corporate responsibility and long-term performance [5]. This is because in the practice of sharia-based business is very tied to the relationship of humans and god.

Several factors that inhibit the development of the Sharia banking industry in Indonesia include: inadequate and educated human resources, regarding human resource management and cultural development and a weak entrepreneurial spirit, relatively small and limited capital funds, there is ambivalence between the concept of sharia management of Islamic banks and their operationalization, the level of trust that is still low from Muslims and academically not yet perfectly formulated to develop Islamic financial institutions in a systematic and proportional way. The implication, the various complexity factors mentioned above, have an impact on people's trust about the existence of Islamic banks among conventional financial institutions [6]

The commitment of the Indonesian government in continuing to encourage market share in Sharia banking, one of which continues to strengthen institutions, regulations and policies that have a systemic impact in the short and long term. Meanwhile, an applicable form of evaluation of Sharia banking practices continues to be carried out, both nationally and globally. National evaluations are carried out by the 
Indonesian government itself, while globally it is usually carried out by the Islamic Research and Training Institute (IRT) and the Islamic Development Bank (IDB) by providing a rating scale for various instruments and products that have been established by each financial institution [7].

\section{METHOD}

The object of this research is the Purwokerto Financial Services Authority $(\mathrm{OJK})$ as the authorized institution in overseeing finance in Indonesia. This type of research is descriptive-qualitative which aims to get a comprehensive picture of the various phenomena studied. Data collection techniques in this study use interviews conducted with the head of OJK, and the adequacy of references in the form of collecting additional data from books, and using documentation in the form of data collection in the form of script or text. While the data analysis is done is to describe and interpret the meaning of the data that has been collected by giving attention and recording as much as possible aspects of the situation under study at the time, so as to obtain a general and overall picture of the actual situation.

\section{RESULTS AND DISCUSSION}

Law Number 21 of 2011 concerning the Financial Services Authority (OJK) guarantees that the $0 \mathrm{JK}$ is formed with the aim that the overall financial service activities in the financial services sector are organized regularly, fairly, transparently and accountably, and are able to realize a sustainable financial system and stable, able to protect the interests of consumers and society. Regionally for the institution of OJK Purwokerto was established on December 31, 2013 in charge of the work area of the Banyumas ExResidency, namely Banyumas Regency, Cilacap Regency, Purbalingga Regency, and Banjarnegara Regency. The Purwokerto OJK was inaugurated by the Chairman of the OJK Board of Commissioners, Muliaman D. Hadad, on April 7, 2015 and having his / her address at Jl. Guerrilla, No. 365 Purwokerto, Central Java. The reason for the establishment of $0 \mathrm{JK}$ is that there has been a process of globalization in the financial system and the rapid progress in information technology and financial innovation creating a financial system is complex, dynamic, and interrelated between financial sub-sectors both in terms of products and institutions. In addition, the existence of financial services institutions that have finance has added to the complexity of transactions and interactions between financial service institutions in the financial system. In addition, there are many cross-cutting issues in the financial services sector, which include moral hazard actions, not yet optimal protection of financial services consumers, and dependence on financial system stability [8].

The role of the financial services authority in increasing the market share of Sharia banking is related to the authority of the OJK itself. The authority and supervision of the OJK on banking include: first, the authority to grant permits, namely the authority to determine the procedures for licensing and the establishment of a bank. Second, the authority to regulate, namely to stipulate provisions relating to the business aspects and activities of banks in order to create healthy banking in order to fulfill banking services desired by the public. Third, the authority to impose sanctions, namely to impose sanctions in accordance with the provisions of the law against banks if a bank is lacking or does not meet the requirements. Fourth, the authority to conduct investigations, namely conducting investigations in the financial services sector, including banking.

In connection with supervision of Islamic financial institutions in Indonesia, OJK is expected to be able to coordinate more with the National Sharia Board (DSN) and the Sharia Supervisory Board (DPS) to ensure the fulfillment of sharia principles in sharia banking operations. The DSN is part of the MUI which is expected to help related parties, such as the Ministry of Finance, Bank Indonesia, and others in drafting regulations or provisions for Islamic financial institutions. The role of DPS and DSN is very important in the supervision of Sharia banking. DPS ensures that Sharia banking operations, products and services are always in accordance with sharia principles. Whereas DSN is an institution that provides recommendations for DPS members who have adequate sharia expertise and competition and publishes national Islamic bank products and services fatwa, so that it can be used as a uniform guide for DPS. Therefore, communication and coordination between OJK and DSN becomes a necessity that must be fulfilled. One effort to facilitate communication between OJK and DSN is by holding a unit or directorate of Sharia banking in the organizational structure.

OJK's strategy in increasing the market share of sharia banking in Purwokerto is generally the same as the national strategy for sharia banking development, namely: first, strengthening the synergy of sharia banking policies between 0JK, the government, and stakeholders. For example, encouraging the formation of the National Islamic Finance Development Committee (KJKS) and encouraging the formation of sharia banking and financial research and development. Second, improving service quality and product diversity, this is divided into three sectors: (1) increasing the role of the Sharia Banking Working Group (WGPS) in the development of sharia banking products, (2) improving the provisions of new products and activities and (3) enhancing activities service excellence and product customization according to the development of consumer preferences. Third, improve the quantity and quality of human resources, information technology (IT), and other infrastructure. This consists of four gross partnership programs: (1) development of syariah banking curriculum standards in universities, (2) competency mapping and competition standard studies and budget allocation policies for the development of Sharia banking human resources, (3) evaluation of related policies or provisions sharing of technology facilities between the parent and its subsidiaries, (4) policies in the framework of developing interoperability, especially between sharia subsidiaries and subsidiaries in a group of companies.

While the activities and programs carried out by OJK perwokerto are in the framework of developing Sharia banking in the working area of OJK Purwokerto, namely: first, carrying out Islamic bank campaign activities (iB campaign) which have been carried out regularly since 2015 through the iB Vaganza Expo. Secondly, implementing "Sharia Sharia" with the agenda of Sharia Financial Services Institutions Exhibition activities. Third, holding a cheap Ramadan market and sharia banking socialization in collaboration with the Indonesian Islamic Bank Association (Asbisindo) as a Banyumas charity. Fourth, the implementation of literacy and inclusion activities in other Sharia banking sectors, such as education socialization in villages / sub-districts, public lectures at universities / colleges, student visits, and so on.

The implications of various policies and programs implemented by the Purwokerto OJK in encouraging sharia banking market share shows positive contribution to the development of Sharia banking. Based on the Purwokerto OJK data in 2017, the development of Islamic banks under the authority of the Purwokerto OJK is divided into five aspects, namely: first, the total assets of sharia banking in Purwokerto are not significant in each year, but in the period of October 2017 the total assets of Sharia banking were very high compared to the previous year with a total assets of Rp. $1,927.36$ billion. Secondly, the total financing of Sharia banking in Purwokerto tends to increase every year, even though the December 2014 period to the December 2015 period has decreased, namely the amount of financing of Rp 1,197, 53 billion, the highest financing in the period of October 2017 yautu amounting to Rp 1,275.03 billion. Third, the total Sharia banking Third Party Funds in Purwokerto experienced a significant increase in each period, but in the period of December 2016 to the October 2016 period decreased by the amount of Rp. 1,391.64 billion.. Fourth, the total Non-Performing Financing (NPF) or problematic credit in every Sharia banking in Purwokerto is the smallest in the period of December 2016 which is $2.80 \%$, but in the period of October 2017 it increased by $3.76 \%$. Fifth, the total Financing to Deposit Ratio (FDR) or the comparison of financing with the number of customer deposits in Sharia banking in Purwokerto tends to decrease in each period (Table 1).

Significant increase in Sharia banking in the region work OJK Purwokerto, there is only one area where the improvement of Sharia banking is less significant, namely Banjarnegara District. Therefore, a special strategy is needed that focuses on the condition of the people in the Banjarnegara Regency region. In addition, the regulation and supervision carried out by OJK aims to achieve more effective regulation and supervision, able to identify problems with financial institutions early and how to resolve them. In addition, one of the positive impacts of the socialization activities carried out by the OJK Purwokerto was the establishment of a good public understanding of Sharia banking, giving rise to public confidence in using Sharia banking products and services. Thus, the existence of more effective and efficient socialization and education that is short-term and long-term continues to be carried out, so that it can continue to improve the development of Sharia banking, both locally and nationally.

Table 1: Data on the Development of the Number of Sharia Banking Offices in the Purwokerto OJK Work Area as of December 2017

\begin{tabular}{|l|c|c|c|c|c|c|}
\hline \multicolumn{1}{|c|}{ Districts } & $\begin{array}{c}\text { Head- } \\
\text { quarters }\end{array}$ & $\begin{array}{c}\text { Branch } \\
\text { office }\end{array}$ & $\begin{array}{c}\text { Branch } \\
\text { office 2 }\end{array}$ & $\begin{array}{c}\text { Cash } \\
\text { office }\end{array}$ & $\begin{array}{c}\text { Office } \\
\text { Network }\end{array}$ & $\begin{array}{c}\text { Payment } \\
\text { Point }\end{array}$ \\
\hline \multicolumn{7}{|c|}{ Islamic Commercial Bank } \\
\hline Banyumas & 0 & 6 & 3 & 2 & 15 & 11 \\
\hline Purbalingga & 0 & 0 & 2 & 0 & 3 & 1 \\
\hline Cilacap & 0 & 1 & 2 & 1 & 9 & 10 \\
\hline Banjarnegara & 0 & 0 & 1 & 0 & 2 & 1 \\
\hline Total & 0 & 7 & 8 & 3 & 29 & 23 \\
\hline
\end{tabular}




\begin{tabular}{|l|c|c|c|c|c|c|}
\hline \multicolumn{7}{|c|}{ Islamic Business Unit } \\
\hline Banyumas & 0 & 1 & 0 & 1 & 2 & 2 \\
\hline Purbalingga & 0 & 0 & 0 & 0 & 0 & 0 \\
\hline Cilacap & 0 & 0 & 0 & 0 & 0 & 0 \\
\hline Banjarnegara & 0 & 0 & 0 & 0 & 0 & 0 \\
\hline Total & 0 & 1 & 0 & 1 & 2 & 2 \\
\hline \multicolumn{7}{|c|}{ Islamic People's Financing Bank } \\
\hline Banyumas & 3 & 2 & 0 & 6 & 11 & 0 \\
\hline Cilacap & 1 & 0 & 0 & 4 & 5 & 0 \\
\hline Purbalingga & 3 & 0 & 0 & 11 & 14 & 0 \\
\hline Total & 7 & 2 & 0 & 21 & 30 & 0 \\
\hline
\end{tabular}

Source: OJK Purwokerto, 2017

The growth and development of Sharia banking in Indonesia have several factors, namely: first, the Muslim population that dominates, so that becoming a market share of Sharia banking and other sharia financial institutions is very potential, even Indonesia can become a global player in world Islamic finance. Secondly, the invitation of a separate Sharia banking, namely Law Number 21 of 2008 concerning Sharia Banking, this can make the key to opening orders in the development of Sharia banking in Indonesia and making the public more trust in Sharia banking because of the support and legal umbrella. Third, Sharia banking can fulfill the public's desire for financial services that meet sharia principles at various business levels. Fourth, Sharia banking provides more varied instruments and forms of banking services with various advantages. Sharia banking seeks to provide better services to the public, including clarity in transactions, trying to run its operations in accordance with Islamic law, and providing a variety of products. Fifth, strong Sharia banking can be the choice of financial institutions that can facilitate capital inflows both in the form of direct investment and other investments. Sixth, academic institutions in the field of Islamic education began to stand up including universities that established faculties or majors in Sharia banking to support the needs of Sharia banking human resources. Seventh, promoting on social media, because the existence of social media accelerates the transfer of information and encourage more participation from public as they will determine the numbers of followers and their responses. Responses of like, comment and share for the programs carried out by OJK [9].

OJK as the supervisor of the financial system in Indonesia, especially the microprudential sector has positive impact on the development of Sharia banking. Not only Sharia banking, but the impact can also be felt by other non-bank Islamic financial institutions such as the Islamic capital market, Islamic insurance, and other sharia financial institutions [10]. The Islamic financial system offers the potential for great benefits for Indonesia's economic development programs. In addition to offering ethics-based transaction models, the Islamic financial system, and the potential to support financial system stability programs and increase access to financial services to all levels of society, including the transformation of poor people to achieve a bright future. This is in line with the government's role in implementing poverty alleviation programs in order to achieve equitable economic development targets.

When referring to the role and function of the OJK, in general the OJK regulates and supervises financial service activities in the banking sector, capital market, insurance, pension funds, financial institutions, and other financial services institutions. OJK has the authority to regulate, supervise, enforce the law as well as educate and protect consumers. So that the OJK's duties and authority for Sharia banking are part of the OJK's duties and authority for banks in general. Therefore, the existence of the OJK is independent in carrying out its duties and functions as stipulated in the law.

In connection with OJK's independence, it can be reviewed in two ways: first, independent relating to dismissal of members of the institution which can only be done based on the reasons set out in the legislation of the establishment of the institution concerned, not as usual administrative agencies that can change at any time by the president because they are part of the executive. Second, the leadership of institutions that are

collective, not only consists of one leader. It means that the leadership in OJK is collegial, this is useful for internal processes in decision making. Besides that, collective collegial leadership is not controlled by a majority coming from certain political parties, and the term of office of the leaders of the institution is not finished simultaneously but alternately. So, the existence of OJK plays a role in overseeing Sharia banking by evaluating the policies carried out, while on the other hand regulators are focused on creating a healthy sharia banking industry regulation.

\section{CONCLUSIONS}

Islamic sharia banking industry in Indonesia will always continue to grow, this is based on the potential and market share of Sharia banking is still very large. So, as for the proactive role of the Financial Services Authority as the institution authorized to supervise and carry out guidance on the financial industry in Indonesia, it should deserve the attention of all financial industry stakeholders. So that the role of OJK Purwokerto in encouraging sharia banking market share is divided into two things, namely: first, conducting supervision so that Sharia banking remains operationally healthy, optimizing banking functions, and conducting sharia financial literacy and inclusion activities. Second, there are several strategies that have been carried out by the OJK Purwokerto in encouraging increased market share of Sharia banking by making ways, namely: (1) strengthening the policy strategy between authority and government and stakeholders, (2) strengthening capital and business scale and improving efficiency, ( 3 ) improve product quality and service.

\section{REFERENCES}

[1] Ullah, S., Harwood, I. A., and Jamali, D. 2018. Fatwa Repositioning: the hidden struggle for Shari'a compliance within Islamic Financial Institutions. Journal of Business Ethics, 149(4), 895-917.

[2] Tabrani, M., Amin, M., and Nizam, A. 2018. Trust, commitment, customer intimacy and customer loyalty in Sharia banking relationships. International Journal of Bank Marketing, 36(5), 823-848.

[3] Undang-Undang N0. 21 Tahun 2011 tentang Otoritas Jasa Keuangan

[4] Makhrus. 2015. Peran Perguruan Tinggi dalam Mendorong Pengembangan Sumber Daya Insani pada Lembaga Keuangan Syariah. Islamadina, 52-66.

[5] Platonova, E., Asutay, M., Dixon, R., and Mohammad, S. 2018. The impact of corporate social responsibility disclosure on financial performance: Evidence from the GCC Sharia banking sector. Journal of Business Ethics, 151(2), 451-471.

[6] Rusydiana, A.S. 2016. Analysis of Sharia Banking Development Issues in Indonesia: Aplikasi Metode Analytic Network Process. Esensi: Jurnal Bisnis dan Manajemen 6(2), 237-246.

[7] Ayub, M. 2018. Maqasid Realisation in Islamic Finance: Components of Framework for Measurement Index. Journal of Islamic Business and Management, 8(1), 1-19.

[8] Sitompul, Z. 2012. Conception and Transformation of the Financial Services Authority (Conception And Transformation Financial Services $\mathrm{Au}$-Thority). Daftar Isi, 343.

[9] Makhrus. 2018. Social Media Based Islamic Philanthropy to Develop Philanthropy Awareness In Indonesia. https://www.atlantispress.com/proceedings/amca-18/25901781

[10] Alamsyah, H. 2012. The development and prospects of Indonesian Sharia banking: challenges in meeting the 2015 MEA." Makalah disampaikan pada Ceramah Ilmiah Ikatan Ahli Ekonomi Islam (IAEI), Milad ke-18 IAEI. 